\title{
Impact of climate change on groundwater and the extinction of ancient "Foggara" and springs systems in arid lands in North Africa: a case study in Gafsa basin (Central of Tunisia)
}

\author{
Naziha Mokadem ${ }^{1,5} \cdot$ Belgacem Redhaounia $^{2,5} \cdot$ Houda Besser $^{3,5} \cdot$ Yosra Ayadi $^{3,5} \cdot$ Faten Khelifi $^{3,5,6} \cdot$ Amor Hamad $^{4,5}$. \\ Younes Hamed ${ }^{3,5}$. Salem Bouri ${ }^{1}$
}

Received: 23 June 2017 / Accepted: 10 July 2018 / Published online: 19 July 2018

(C) The Author(s) 2018

\begin{abstract}
The rising increase in groundwater abstraction to serve the industrial sector and to fulfill the agricultural and domestic needs, coupled with severe drought periods during the past decades, leads to a growing deficit of water. The drawdown of piezometric levels and progressing degradation of water quality are the main consequences of such intensive exploitation. In this connection, the present study emphasizes the major effects of groundwater resource overexploitation in Southern Tunisia, and it evaluates its impacts on the ancient mkayel "Foggara" system. Although it is crucial role in various aspects of modern society, especially in Gafsa basin ("El Guettar region", central of Tunisia), this system is facing an increasing abandonment with the introduction of new technologies in response to the irrational exploitation. The mkayel are particularly susceptible to impairment by groundwater withdrawals with modern wells and pumps. In arid regions, the proper conservation and maintenance of the mkayel systems constitute promising alternatives for sustainable water management and for supporting economic development. In the past few decades, we witness a gradual disappearance of these galleries by an average loss of a dozen of mkayels per year for over half of a century expressed by a significant drop in the discharge of the 800 functional mkayels, enough to irrigate 450 ha, from $1000 \mathrm{l} / \mathrm{s}$ in 1900, $200 \mathrm{l} / \mathrm{s}$ in 1960, and $5 \mathrm{l} / \mathrm{s}$ in 1975 to $0 \mathrm{l} / \mathrm{s}$ in 2011 related to technical, social, and environmental causes. Despite the continuous extinction of mkayels, many Arabic countries still consider it as an important system of water transfer.
\end{abstract}

Keywords Overexploitation · Groundwater · Mkayel · Arid lands · Gafsa basin · Tunisia

Belgacem Redhaounia

belgacem.redhaounia@yahoo.fr

Naziha Mokadem

nazouhmoka@gmail.com

Houda Besser

besserhouda@gmail.com

Yosra Ayadi

ayadiyosraa@yahoo.fr

Faten Khelifi

fatenkhlifi@outlook.com

Amor Hamad

hsamir2001@gmail.com

Younes Hamed

hamed_younes@yahoo.fr

Salem Bouri

bouri.salem@yahoo.fr
1 Water, Energy and Environmental Laboratory (L3E)National Engineers College of Sfax (Tunisia) (ENIS), Street of Soukra Km 3.5, 3038 Sfax, Tunisia

2 Georesources Laboratory, Water Researches and Technologies Center Borj-Cedria (CERTE), BP 273, 8020 Soliman, Tunisia

3 Research Unity Water, Energy and Climate, Faculty of Sciences of Gafsa, Gafsa, Tunisia

4 Research Unity B. Water and Environmental Faculty of Science of Tebessa, Tebessa, Algeria

5 International Association of Water Resources, Southern Mediterranean Basin, Gafsa, Tunisia

6 Department of Earth Sciences, Faculty of Sciences of Bizerte, University of Carthage, Jarzouna, 7021 Bizerte, Tunisia 


\section{Introduction}

Groundwater resources are of great importance for agricultural development in arid and semi-arid areas around the Mediterranean basin and especially in North Africa, where surface waters are scarce and irregular. Hence, aquifers are intensively exploited to satisfy growing agricultural, industrial touristic, and domestic needs. The accelerated industrialization process in combination with rapid population growth and agricultural activities has brought the risk of increasing the pollution index and/or degradation (quantity and quality) in natural resources (water, soil, etc.) (Morrison et al. 1990; Hassanzadeh et al. 2011).

In Northern Africa, the deep aquifers are used to be the main water source fulfilling many purposes through their natural discharge. Furthermore, artesian springs represent a source of life for the traveling nomads in the desert. In those arid regions characterizing by the scarcity of runoffs and the high temperature and evaporation rates, the lack of alternative water resources leads to an overexploitation of the groundwater resources. The intensive groundwater exploitation causes the degradation of its quality, soil salinization, and even desertification (Mamou et al. 2002). A decreasing trend in precipitation values and an increase in groundwater exploitation by pumping have led to the subsequent overexploitation of the aquifers (Vrbo et Lippanen 2007), causing a significant fall in piezometric levels, water-quality deterioration, increase of abstraction cost, ecological damage, increasing pumping costs, and decreased wells yields (Konikow et al. 2002).
The term "intensive groundwater use" is applied when exploitation induces significant changes on natural aquifer dynamics (Custodio et al. 2005). Although the aquifer overexploitation is still ambiguous and controversial term, its impacts are commonly observed in many arid and semiarid regions all over the world (where aquifer recharge is limited), related to competing demands that grow on limited resources (Morris et al. 2003). The term groundwater mining is used when conscious and planned abstraction rate greatly exceeds aquifer recharge (United Nations 1992) owing to groundwater overdraft with a long-term extraction exceeding both natural and induced renewable water resources. Despite the fact that aquifer over drafting can be temporarily beneficial within a long-term water management strategy (Harou et Lund 2008), it reveals a huge challenge in arid and semi-arid regions, for the sustainability of limited groundwater resources coupled with mismanagement leading to aquifer depletion and groundwater-quality deterioration (IGES 2008).

Known under different names: Khettara (Marrackech), Qanat and kareez (Iran), Kariz (Afghanistan and Pakistan), Falaj and (plural aflaj) (Oman and United Arab Emirates), Kahriz (Iraq), Karez (Afghanistan), Qanat romani (Jordan and Syria), Qanate and Ingruttati (Italy), Manbo (Japan), Hoyas (Latin America), Jingquen (China), Galeria (Spain), Kahn (Baloch), and Foggara (Algeria); the mkayel system (plural of Mkoula or Mkayels) in Tunisia is an underground gallery with gentle slope draining the water from the upstream aquifer to the drier land downstream towards the palm using gravity flow conditions (Fig. 1a). The mkayel irrigation is an old system of underground water channels where water flows by gravity from the "mother well" dug
Fig. 1 a Localization of the mkayel in El Guettar basin; b characteristic of the mkayel conduits in El Guettar basin; c Lalla El Galâa "religious beliefs" in El Guettar basin; d salinization of the soil and halophytes plants in El Guettar basin

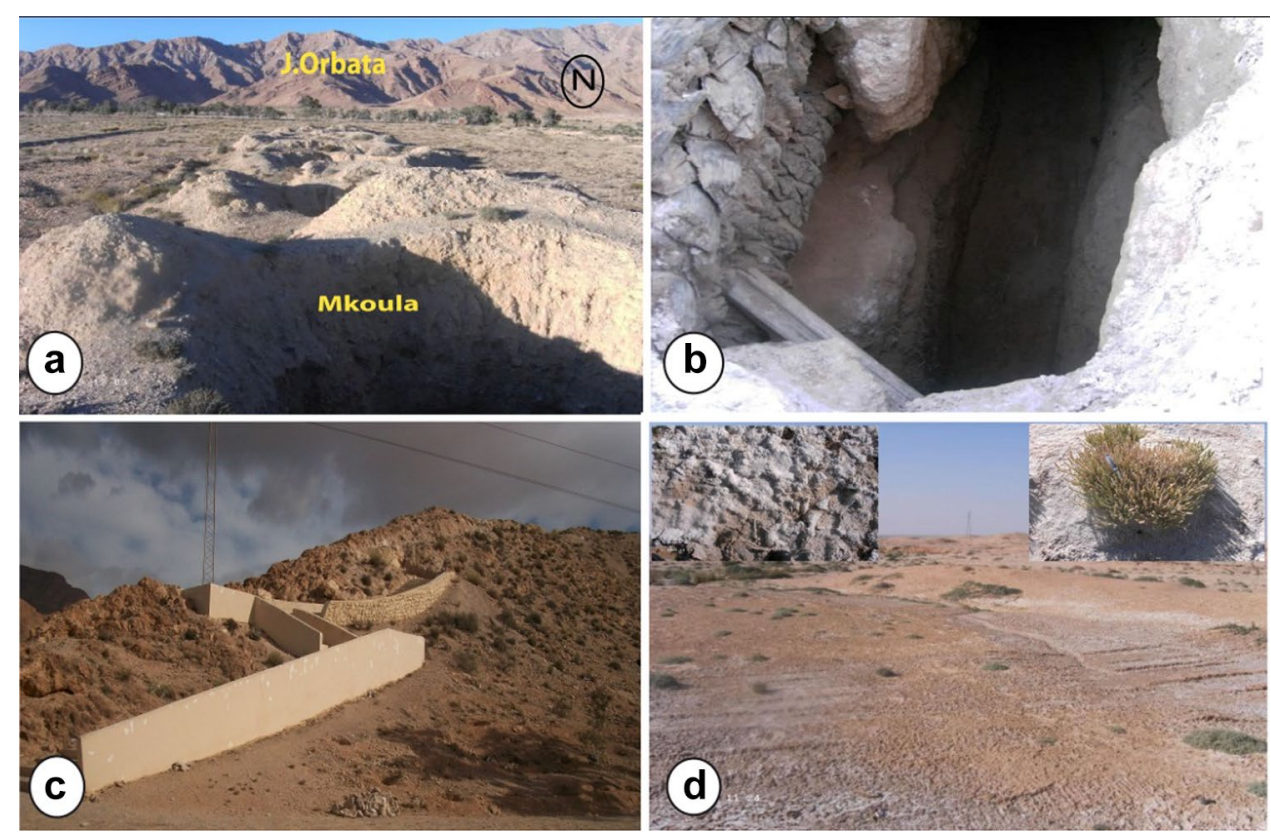


into the water table (Fig. 1b). The water channel is underground for a distance of a few hundred meters to a few kilometers before it emerges from the ground at the "day light point'. The mkayel water, collected from natural source or through infiltration of groundwater, can be used for different purposes, especially irrigation. In North Africa (Tunisia, Algeria, and Morocco), a major supply of fresh water is obtained from underground infiltration tunnels known as the mkayel. The advantage of this system is the reduction in the amount of water lost by evaporation. This process uses a system of tunnels with slope length that may reach $10 \mathrm{~km}(1) / 2 \mathrm{~km}$ (1), equipped with a series of vent wells spaced 5-25 m (Fig. 1a). The mkayel as a technical system is associated with social work led by a committee of wise men, called Jemâa, whose role is to direct and oversee the maintenance of the mkayel and the distribution of its water.

The mkayel system consists of a part above the surface and of an underground part divided into the "water production section", underneath the groundwater level of the surrounding area and the "water transport section", which transports the water to the surface. This section is usually lined with plastering on the sides to prevent leakage of water. The gradient of the tunnel is very precise, and should not be too low to ensure water transport and should not exceed $5 \%$ to inhibit the erosion of the hosted rock or sand unit in which the tunnel is dug. The mkayel drains the water from an unconfined aquifer "Quaternary fluvial sand and gravel" on the slope of a hill and conveys it to the oasis thanks to the land natural gradient. The conduits which are usually $0.75-1 \mathrm{~m}$ wide and $1-1.5 \mathrm{~m}$ high (Fig. 1b) in length vary from less than $8-12 \mathrm{~km}$ and their discharge rate ranges from less than one to more than $1000 \mathrm{l} / \mathrm{s}$ (Trousset 1986).

The mkayel system is a friendly environmental method playing a crucial role in the groundwater management in arid and semi-arid regions where groundwater is the unique available source of freshwater to meet different supplies, especially for agriculture activity needs, as about one-third of the world's landmass is irrigated by groundwater; in USA, $45 \%$ of cultivated land is irrigated by groundwater resources, while in Iran, Algeria, and Morocco, the percentages stand at 58,67 , and $75 \%$, respectively.

The mkayel technology, known as Falaj, an invention is Oman, which is considered the home of this technique (Desruelles et al. 2016), has been dated to 3000 BCE (Orchard and Orchard 2007), but its third millennium attribution is still debated (Charbonnier 2014). According to Cleuziou and Tosi $(1998,2007)$, the falaj could have been used since the beginning of the third millennium BCE at Hili (UAE), but evidence of hydraulic structures such a aflaj and date cultivation are more well known and numerous for the Iron Age (Magee 2004; Al Tikriti 2002; Cordoba 2013) before it spreads to others cultures. Actually, these traditional systems exist in different regions all over the world in Northern Africa, Southern Europe, Latin America, Asia, and Arabia. They constitute a World hydraulic Heritage, referring to the igneous knowledge of hydrology, hydrogeology, and engineering of people in the past aiming water management and maintenance of agricultural production. The mkayel systems were supported by strong reliefs and traditions, and they were handled as a legacy on which the social arrangement was based (Fig. 1c) (Bonine and Mc Lachlan 1989).

The social hierarchy and economic status were judged according to their ownership rights to the amount of water from the mkayel 1. For example, in Iran, the residents of more eminent households of landlords, merchants, and religious leaders were located in the upper section of the mkayel-based settlement areas where the water is clean and plentiful (Bonine 1989; English 1998). Marriage ceremonies were performed between subtle, gentle Mkoula (female), and gushing, spurting Mkoula (male) as a ritual. In Tunisian, the mkayel developed in the Sahara plateau for over 4500 years (Bordereau 1986; Tlili 2009). Presently, some of the rituals are still being followed to some regions in the rural settlements and villages of Tunisian territory. Nowadays, the mkayel systems in El Guettar basin attract thousands of Tunisian and international tourists.

In this connection, the present paper aims, first, at evaluating groundwater overexploitation effects in arid land and, second, the assessment of technical, environmental, and socio-economic problems threatening the functioning of the mkayel in the Gafsa basin (central of Tunisia).

\section{Methodology}

\section{Study area}

The study area is limited by the central and southern Atlas of Tunisia, about " $100 \mathrm{~km}$ " at flight bird south of a large island (Kasserine Island "Tunisian Atlas"). This zone is characterized by E-W- and NW-SE-oriented faults and of NE-SWtrending anticlines, separated by large synclinal basins (Ahmadi et al. 2006; Hamed et al. 2010; Mokadem et al. 2016). The study area is an oasis village, scanning an area of 9000 hectares of which $70 \%$ are covered by palm trees perched at the foot of the Ben Younes-Orbata mountains (Gafsa Monts). It is considered as a national natural feature holding a great part of the civilizational heritage of the country. It is located in southwestern Tunisia. This corresponds to UTM WGS 1984 coordinate lines: $X 1=420,000 \mathrm{~m}$ and $X 2=520,000 \mathrm{~m} ; Y 1=3,700,000 \mathrm{~m}$ and $Y 2=3,840,000 \mathrm{~m}$. It is limited in the West by the Algerian frontier, in the North by the Gafsa Chain (J. Ben Younes and J. Orbatta), in the East by the Gulf of Gabes, and in the South by the Northern Chotts range (J. Sehib and J. Berda) and by Djerid chott 


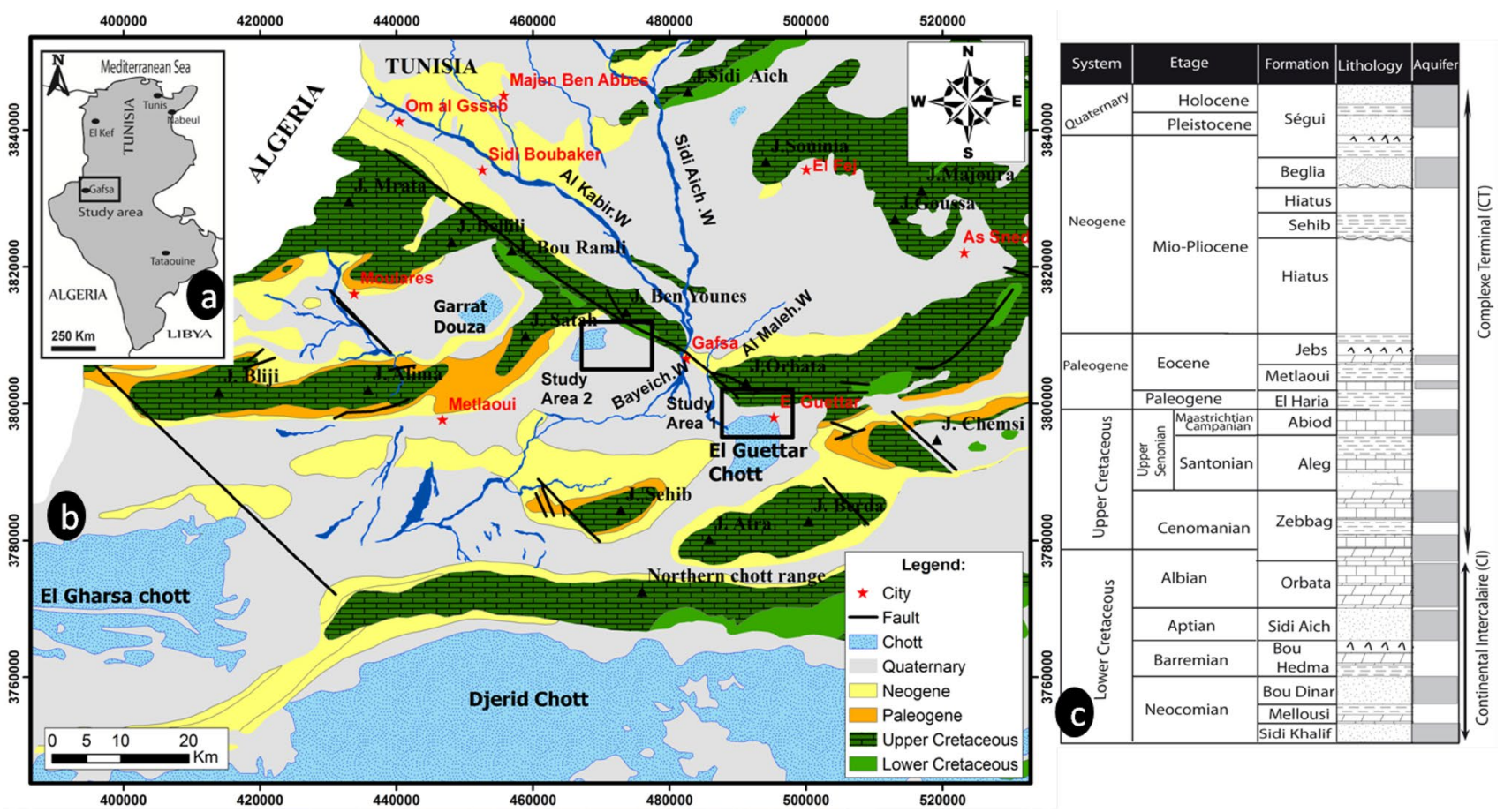

Fig. 2 a, b Simplified geological map of El Guettar basin and the localization of mkayel area (Southwestern Tunisia); c lithostratigraphic column of the study area

depression (Fig. 2a,b). Tunisia, bordering the Mediterranean, represents a climatic transition zone expressed by the existence of two dominant climate types; the Atlantic and the Mediterranean (Celle 2000; Celle-Jeanton et al. 2001). The absence of high mountains in the Southern province allows the integration of Saharan air masses. The study area, in the Southwestern part of the country, lies in a semi-arid region. It is distinguished by sandy wind during autumn and spring, and the sirocco wind from south west direction in the summer. The mean annual precipitation is about $170 \mathrm{~mm}$, the annual temperature has an average of $22{ }^{\circ} \mathrm{C}$, and the potential evapo-transpiration is about $1680 \mathrm{~mm} /$ year (Hamed et al. 2010; Mokadem et al. 2013, 2015; Besser et al. 2018). The drainage network is not so dense. It is composed of El Kebir, Sidi Aïch, Bayeïch, El Melah, Majni, Lortess, Berda, and As Sad... non-perennial wadis which collect surface runoff from the surrounding hills of Gafsa ranges (J. Sidi Aïch, J. Ben Younes, J. Orbata, J. Chemsi, and J. Berda) and the Algerian territories. The surface water of these wadis is carried to the large continental depression of Chott El Guettar and of Djerid Chott (Fig. 2a,b).

The study area is a typical example of arid regions where groundwater resources are intensively exploited to supply water needs of agricultural, demographic development, and of the industrial activities related to the Company of Phosphate of Gafsa "CPG". The mkayel acquisition technique of groundwater has been the technique the most appropriate in a region hostile to life. The development and spread of the mkayel throughout the region of El Guettar helped the installation and the maintenance of oasis systems for many centuries. Today, this socio-cultural heritage, the pride of all the oasis population, is endangered by a loss of a dozen of these mkayels per year.

\section{Geological and hydrogeological settings}

The study area, in the southern Tunisian Atlas domain, represents a transitional zone between two structurally different domains: in the South, the simple and monotonous Saharan Platform and, to the North, the complex central Tunisian Atlas Mountain belt with its major thrust faults, diapirs, and old compression structures in the North (Ahmadi et al. 2006). As shown in the geological map (Fig. 2b), several east-west anticlines emerge in the Northern and Southern borders of the basin. According to the preserved sedimentary sequence, the marine marly limestone of the Lower Cretaceous related to the Zebbag formation represents the oldest deposit. It outcrops at the Orbata range and in the proximity of the major fault extending along Gafsa range and in the northeastern border of the basin. Zebbag deposits are overlaying by Upper Cretaceous limestones of Abiod formation and the phosphate-rich limestone of the Metlaoui Eocene group, outcropping along the southern border of the Berda and Sehib ranges. The sedimentation becomes shallower 
with the continental Neogene formations, related to Sehib, Beglia, and Segui (Mio-Plio-Quaternary) formations which outcrop in the central part of the basin (Fig. 2b).

The lithostratigraphic column (Fig. 2c), extending from the Cretaceous to the Quaternary, shows two main stratigraphic units. The first unit is represented by the marine Cretaceous and Palaeogene deposits of the Sidi Khalif, Melloussi, Boudinar, Bouhedma, Sidi Aïch, Orbabta, Zebbag, Aleg, Abiod, El Haria, Metlaoui, and Jebs formations, while the second is formed by the continental Neogene and Quaternary deposits of the Sehib, Beglia, and Segui formations. These two stratigraphic units are separated by an important sedimentary hiatus extending from the Middle Eocene to the Early Miocene. Tectonically, the main tectonic activity in the El Guettar basin dating from the Plio-Pleistocene age, probably Villafranchian, is still active, having current seismic activity (Dlala and Hfaiedh 1993).

According to the lithostratigraphic column (Fig. 2c) and the conceptual models (Fig. 7), the preserved sedimentary sequence reveals four main aquifers levels in the study area consisted of four important aquifer levels hosted, respectively, from the bottom to the top, in the Turonian deposits (Zebbag Formation) in the Upper Cretaceous units (UC) (Abiod Formation), the Miocene sediments (M) (Beglia Formation), and the Plio-Quaternary formations (PQ) (Segui Formation). These hydrostratigraphic units from the multilayered aquifer system of the Complexe Terminal (CT) and they are intercalated by impermeable clay horizons. Besides to $\mathrm{CT}$, three aquifer levels expressed by Lower Cretaceous permeable continental formations of Orbata, Sidi Aïch, and Boudinar (Fig. 2b,c) form the second multi-layered aquifer system of the Continental Intercalaire (CI). The transboundary system of CI of North Africa is one of the largest confined aquifers in the world. It is hydraulically continuous from the Atlas Mountains in Algeria (recharge area) to the Chotts of Tunisia (discharge area) (Hamad et al. 2018; Hadji et al. 2018). The fresh recently infiltrated groundwater is not affected by pollution and characterized by low values of electrical conductivity (EC) and $\mathrm{Ca}-\mathrm{Mg}-\mathrm{HCO}_{3}$ water type is attributed to the recharge area. The EC values show a gradual increase towards the down parts of the basin (El Guettar Chott and Djerid Chott).

\section{Data collection}

The region of El Guettar consists of several mkayel located in the southern zone of the Jebel Orbata, in the towns of Lortess and El Guettar. They belong to the hydrographic basin of Chott El Gharsa and the sub-basin of Chott El Guettar located in the municipality of El Guettar Ouest, delegation of El Guettar, Gafsa governorate. The oasis of El Guettar received water from the mkayel through the water table located in the foothills of the Jebel Orbata, on a glacis of
$10 \mathrm{~km}$ in length. The platform is formed by detrital materials belonging to Quaternary deposits, and characterized by their thick increasing towards the mountain and decreasing near the Chott of El Guettar. The mkayel is located to the south of the road that connects Gafsa with the Guettar. A decreasing trend in precipitation rates and an increase in groundwater exploitation by pumping have led to subsequent overexploitation of the aquifers, causing a significant fall in piezometric levels in El Guettar region. Furthermore, the number of shallow wells in El Guettar region has increased from 25 during the 1980-300 in 2016 and the deep wells increased from 1 during the 1980-16 in 2016 (DGRE (Direction Générale des Ressources en Eau) 2011). The exploited volume (Fig. 3) increased from $0.4 \mathrm{Mm}^{3} /$ year in $1980-1.8 \mathrm{Mm}^{3} /$ year in 2016 (DGRE (Direction Générale des Ressources en Eau) 2011). The piezometric level of shallow aquifer in El Guettar basin is composed of two piezometers (well $\mathrm{N}^{\circ} 30$ and $\mathrm{El}$ Guettar piezometer). Indeed, the curves of evolution of the static level show a decline in the depth of the water (Figs. 4a, b). The transmissivity of the PQ shallow aquifer ranges from $2.8 \times 10^{-2}$ to $27 \times 10^{-2} \mathrm{~m}^{2} / \mathrm{s}$, while the permeability varies between $7.3 \times 10^{-4}$ and $15.2 \times 10^{-4} \mathrm{~m} / \mathrm{s}$ in Segui/Beglia formations (Mokadem et al. 2015).

\section{Results}

The increased use of the limited low renewable groundwater resources in Gafsa basin to buffer drought years, to compensate surface water deficit, and to maintain agricultural activities constitutes a source of conflicts between competitive sectors (Trousset 1986). According to the study of (Hamed et al. 2010), the exploitation rates in Northern Gafsa have evolved from $79 \%$ in $1998-115 \%$ in 2014 (2.5\% per year) (DGRE (Direction Générale des Ressources en Eau) 2011). This irrational exploitation leads to a decrease of piezometric level expressed by a drawdown of groundwater table

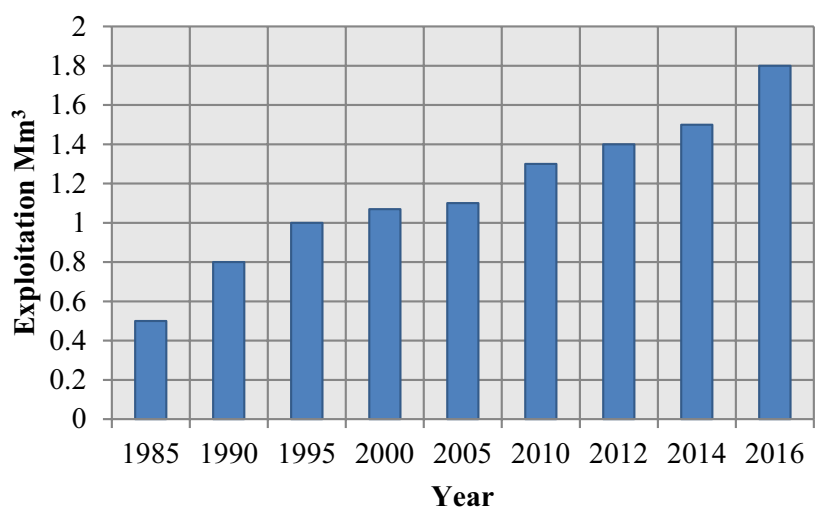

Fig. 3 Annual exploitation of shallow aquifer of El Guettar basin 

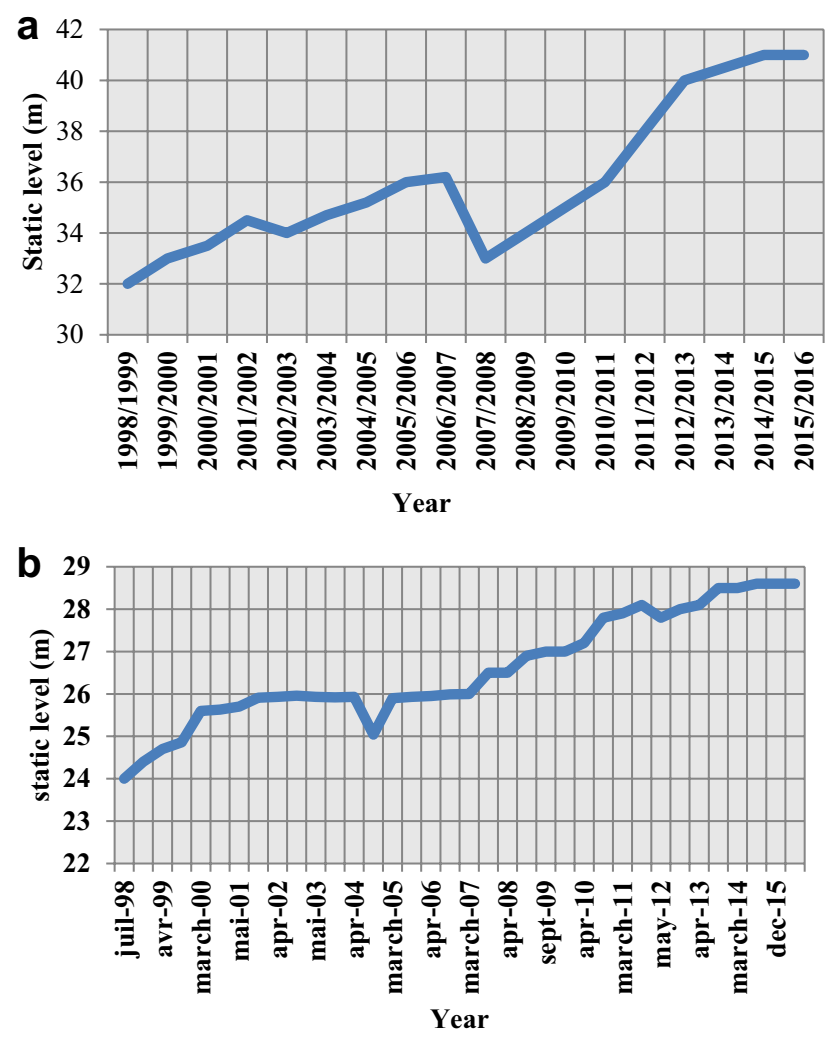

Fig. 4 a Evolution of static level of El Guettar basin (El Guettar piezometer); $\mathbf{b}$ evolution of static level of El Guettar basin (well $\mathrm{N}^{\circ} 30$ )

between 2 and $6 \mathrm{~m}$ (Hamed et al. 2010); a rising of pumping rate from $56 \mathrm{l} / \mathrm{s}$ in $1933-210 \mathrm{l} / \mathrm{s}$ results in the extinction of artesianism in Gafsa basin.

In this connection, the groundwater in the study area has TDS values ranging from 1 to $3 \mathrm{~g} / \mathrm{l}$. The gradual increase of salinity levels may be explained by the overexploitation impacts, by the enhanced rock-water interactions and the leaching of evaporate terrains expressed by a slight rise of TDS values in 2012 comparing to 1996 ( $0.03 \mathrm{mg} / \mathrm{l}$ per year) referring to the contribution of the leaching of evaporate sediments during heavy rainfall events of 2002 and 2005 in groundwater mineralization (Hamed et al. 2010).

\section{The water quality of the mkayel and the springs in Gafsa basin}

The mkayel have usually been the main source of good water quality for drinking purposes depending greatly on the topography of the region. The groundwater available farther from the mountains (Gafsa chain: J. Orbata) reveals generally a poor quality related to various recharge zones and non-point contamination source, while, in the proximity of the mountains, the groundwater is more available with a better quality. It is known that the silting is the main threats

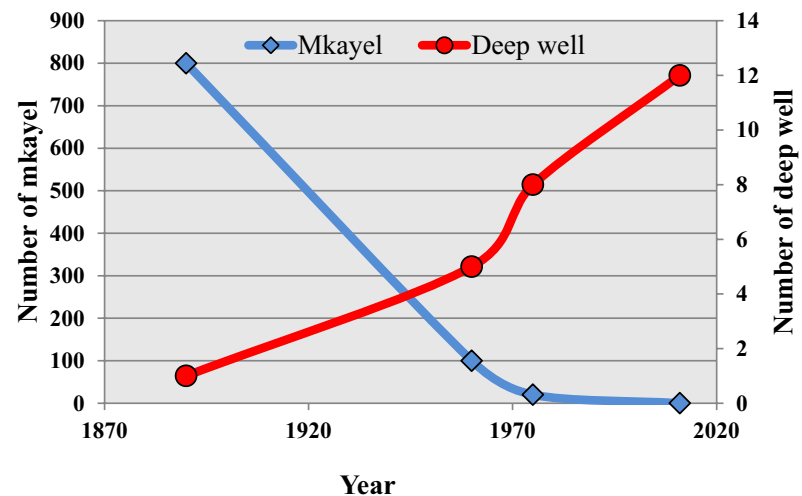

Fig. 5 Changes of the number of mkayel and wells in El Guettar basin

of the sustainability of mkayel unless the maintenance is performed periodically to clean up the tunnels from the accumulated sediment. Since the mkayel water slowly travels a long distance $(\approx 2 \mathrm{~km})$, silt and clay particles tend to settle along the tunnel before the water reaches to the storage pool ensuring a better water quality for drinking purposes. (Hamed et al. 2010) states that the recharge through the mkayel keeps the salinity level of the soil under control, since the fresh water is transferred from mountain plateaus to the lower plains that have saltier soils; resulting in the proliferation of halophytes plants (Fig. 1d).

\section{Current status of springs and mkayel in Gafsa basin}

Due to the rapid population growth and the technological advances, the mkayel systems cannot meet the water requirement of large-scale agriculture practices, and consequently, they are losing their importance in agricultural production. In addition, the introduction of the industrial sector of the phosphate company of Gafsa "CPG" using a number of pumped wells has accelerating groundwater depletion (phosphate washing which requires, 1800 1/s) (Hamed et al. 2010) and the abandonment of the mkayel systems.

Figure 5 shows the decreasing trend in numbers of the mkayel and great increasing trend of deep wells from late 1900s to 2014 in El Guettar basin (DGRE (Direction Générale des Ressources en Eau) 2011; CPG (Tunisian phosphate industry) 2010). After the independence of the republic of Tunisia (1956) and in the year of 1957, the number of the mkayel in operation in the El Guettar region of Tunisia was 100 and the annual water supply amounted to $200 \mathrm{l} / \mathrm{s}$, while the irrigated area was about 260 ha. However, in 1976, the number of the mkayel in operation dropped to 4 , and the annual groundwater supply increased to $600 \mathrm{l} / \mathrm{s}$ with a total irrigated areas of 345 ha. 
This is mainly explained by increased numbers of deep wells from one during the 1980-15 in 2016 in the studied region and the groundwater drawdown. The primary difference between the mkayel and deep wells is their sustainability: the mkayel water is a renewable resource, because the rate of water flow in the Mkayels is controlled by the level of the water table, while deep wells can extract groundwater depending on the demand, regardless of the recharge rate of the aquifer.

In addition, the collapse and landslides of these mkayel (Fig. 6a, b), and the silting and clogging of the mkayel by plants' roots are the main environmental problems that affect the mkayel of El Guettar basin (Gafsa area). Actually, over 400 non-functional mkayels in the region of El Guettar are exposed to the phenomenon of silting (Sahara climate). In addition, the seismic activity in the El Guettar-Gafsa region facilities this degradation, the expansion of agricultural areas, and the urban construction (Fig. 6c).

Due to the anthropogenic discharges (Fig. 6d, e), the rapid growth of the population (307.513 inhabitants in 1990 and 337.331 inhabitants in 2017), technological progress and overexploitation of water $\left[0.4 \mathrm{Mm}^{3}\right.$ in $1980-1.8 \mathrm{Mm}^{3}$ in
2016 (CRDA 2016)], and the water erosion, the mkayel is no longer useful for agriculture in the study area as they cannot provide the needed quantity. Therefore, they lost their importance in agricultural production. In addition, the introduction of the industrial sector of the "CPG" has accelerated the depletion of groundwater resulting in the extinction of these mkayels which is transformed generally in septic tanks.

\section{Effect of climate change in water resources in Gafsa basin}

Climate change has long-term impacts on water resources in Arab countries (Hamed et al. 2017; Gayar and Hamed 2018). The conceptual models, shown in Fig. 7, summarize schematically (without regard to paleo crusts) the different stages of the hydrodynamic and geochemical evolution of groundwater table (Quaternary alluvial, CT and $\mathrm{CI}$ aquifers) and its eventual contamination by the brines Chotts. The exploitation of these aquifers and their long-term replenishment are largely controlled by longterm climate conditions which their variability can be disastrous. In the 1900s, springs and some deep boreholes
Fig. 6 a, b Collapse and erosion of the mkayel; $\mathbf{c}$ agricultural and urban construction (soil subsidence and the distraction of buildings) in the mkayel area in El Guettar basin; d, e anthropogenic discharges in the mkayel area in El Guettar basin
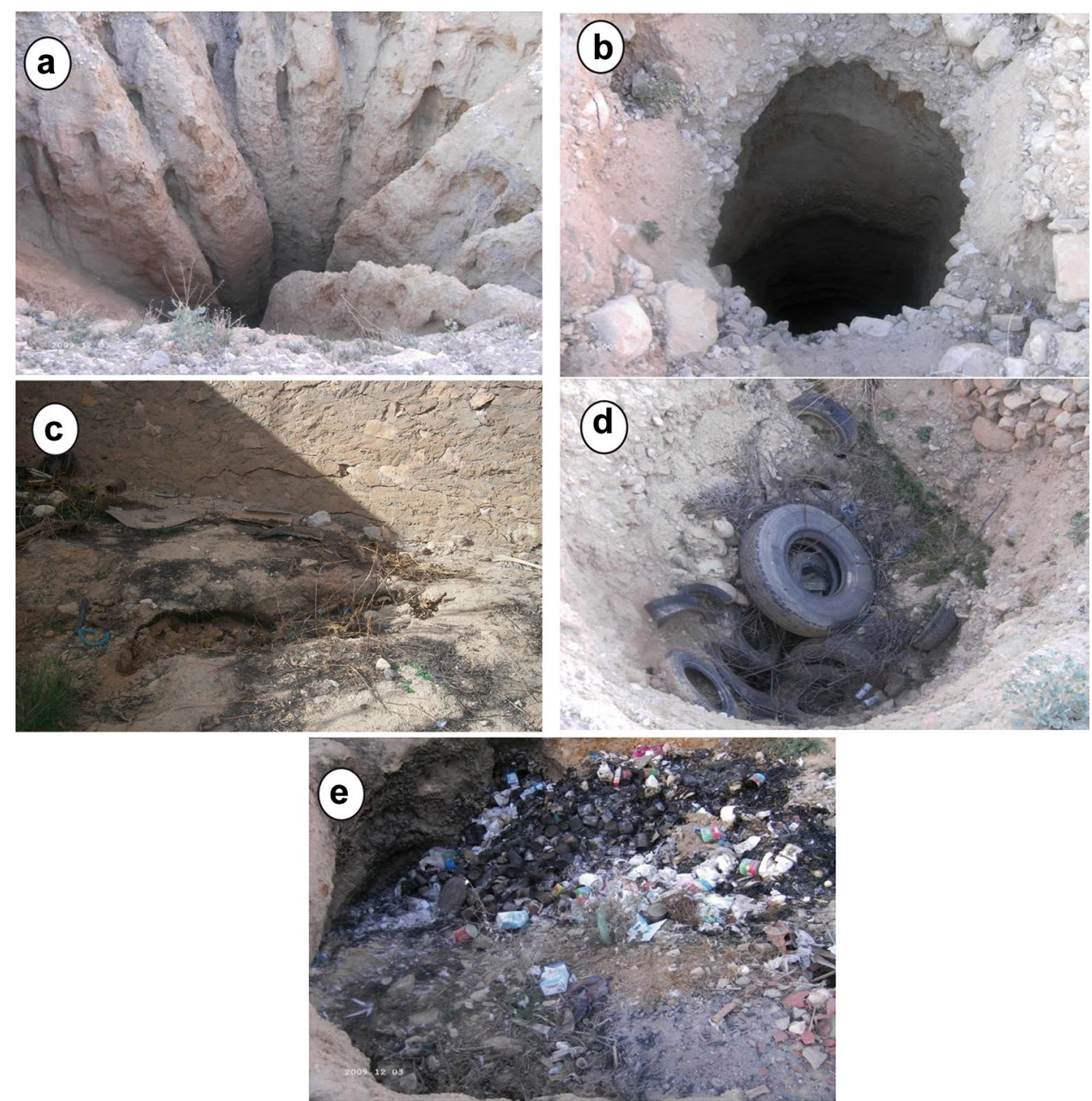

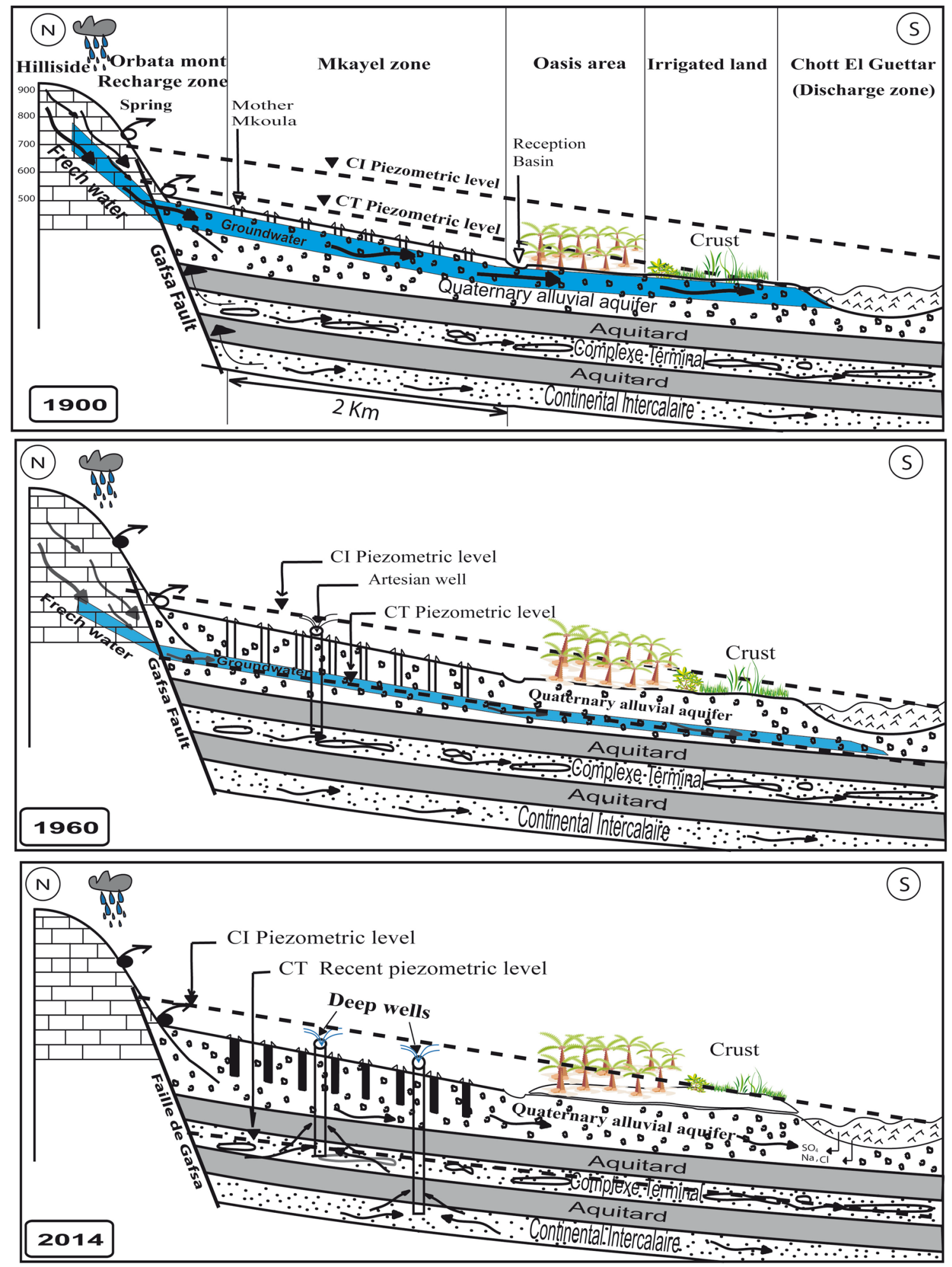

Fig. 7 Conceptual models of the hydrodynamic evolution of water table in El Guettar basin during (1900-2014)

tapping the CT and CI aquifers provided water irrigation for old oasis systems. At that time, potentiometric head of CT and CI reached the top of Orbata Mont (Gafsa chain) and feed power springs with $800 \mathrm{l} / \mathrm{s}$ in the beginning of the last century (Mamou 1989) (stage-1 “1900”, Fig. 7). Between 1960 and 2014, the overexploitation of these 
aquifers has contributed to the loss of the artesian conditions and the decline of CT and CI groundwater level. The return of irrigation flow contributes in the formation of perched local "oasis type aquifer" in oasis areas, where salts concentrate and form gypsum crust (stage-2 "1960", Figs. 7,6e). Stage-3 "2014" summarizes the current mechanism of the water mineralization by the dissolution of salt crust. The decline of the water table permits an eventual brine Chott invasion. Indeed, local signs of water table were recorded in the oasis surrounding El Guettar Chott, with predominance of evaporate sediments (halite, gypsum, and hydrate), but they still limited in time and in space.

Even though that many springs have extinct due to the overexploitation, the debit of some others had only diminished. The significant decrease in the springs debit in Gafsa basin is a result of the excessive use of groundwater by the phosphate industry (CPG). Recently, the exploitation of Sidi Ahmed Zarroug shallow aquifer has stopped. Thus, the piezometric level returned gradually to its natural equilibrium, and Aïn Echfaa spring, which had been non-functional for quite sometime, is now functioning normally (Fig. 8).

\section{Discussion}

\section{Countries which have conserved the mkayel}

The utilization of the mkayel systems is controlled by the geographic position, and the hydrological and the climate conditions of the regions. In Southern Morocco, the people live within oases relying mainly on the traditional water systems named khattara. On the margins of the Sahara Desert, the isolated oases of the Draa River valley and Tafilalt have relied on the traditional khattara water for irrigation since the late fourteenth century (Oshima 2001). In Marrakech and the Haouz plain, the khattara have already dried up since the 1970s owing to widespread use of motor-pumps in the upstream area. There are about 570 khattara, but only around $270(50 \%)$ are still in use in the Tafilaft region (Ben Brahim 2003). The construction of the Hassan Adahkil Dam's on local water tables is played an important role in the reduction of half khattara (Motiee et al. 2006). Although the reduction in numbers of khattara is caused mainly by various reasons like the economic difficulties related to drought (Oshima
Fig. 8 Conceptual model of hydrodynamic of Aïn chfaa spring

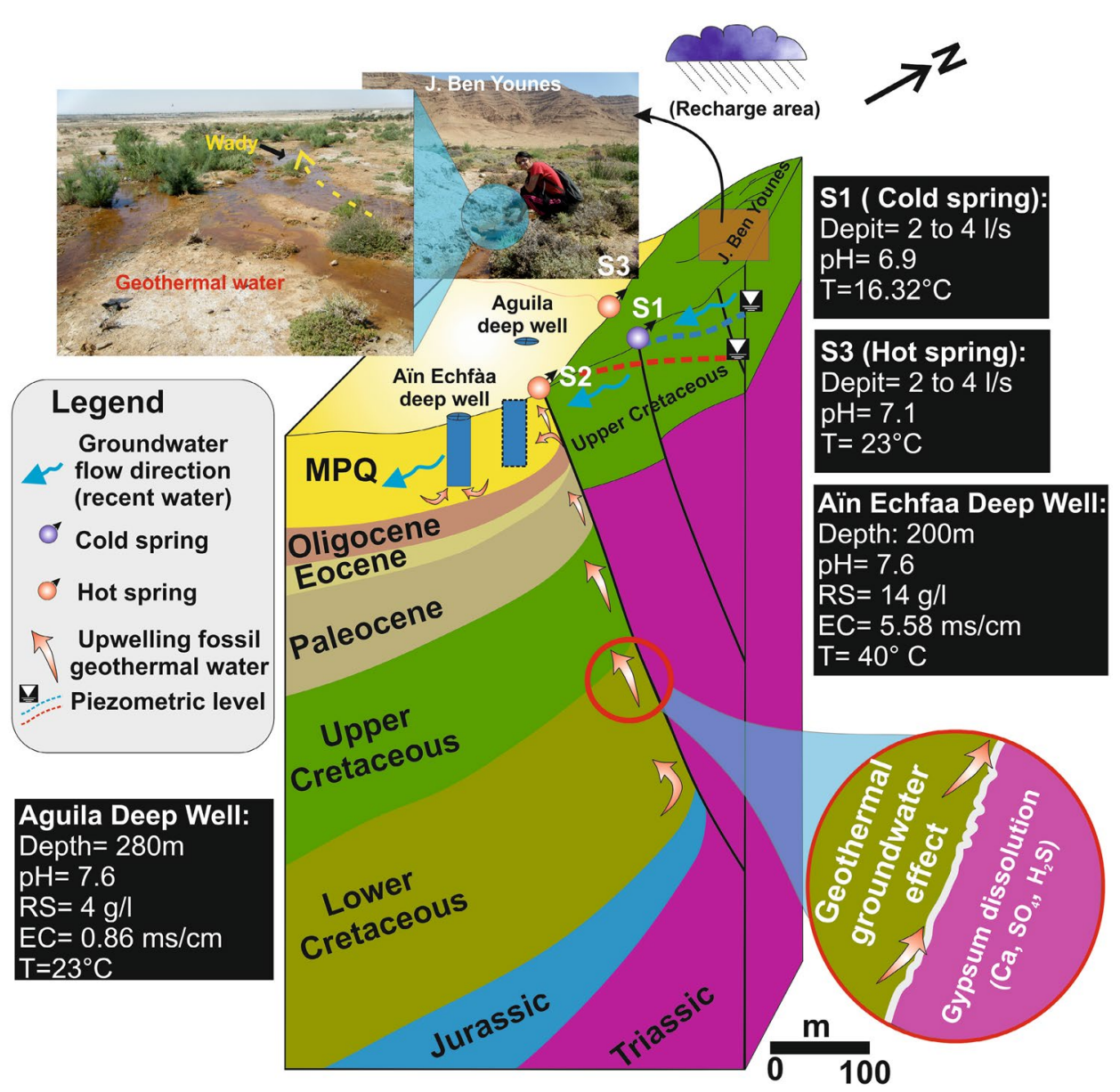


2004). Morocco is yet one of the principal countries in North Africa that has used these galleries (khettara).

Even for Algeria, the foggara is used for irrigation at large oasis, such as that at Gourara and at Touat (an area of Adrar $200 \mathrm{~km}$ from Gourara). In this region, the total length of the foggara is estimated to thousands of kilometers. Despite sources suggest that the foggaras may have been in use as early as 200 AD. The National Agency of Water Resources (N.A.W.R) in Algeria reported the number of foggaras dug in the Touat and Gourara is 1400, only 903 foggaras functional between 1998 and 2001.

Underground water is an important source of fresh water in Egypt; its importance is augmented by the fact that it is the unique source of water in the Egyptian desert that constitutes 95\% of Egypt's total area. As early as the second half of the fifth century BC, there was evidence that water was being used via the mkayel.

Although they are numerous, most of the Kahriz in Iraq are useless because of their poor condition especially in the northern region where hundreds of them are abandoned. However, for the remaining ones, the water production could be very high (covering 15\% of drinking water and $85 \%$ of farming needs). It is very effective in agriculture. Furthermore, each Kahriz could cover the needs of 100 farm. Aside from their economic value, the Kahriz are of great importance for many reasons. Their cultural and social values are undeniable. They represent the old traditional knowledge in its best features.

The distribution of qanats in Syria is located in different places such as Damascus, Homs, and in the Steppe areas. The qanats were principal sources of drinking water and irrigation for agriculture in past. The water's local system of rights and regulations controls its division. There are two types of qanats in Syria: infiltration qanats and spring qanats. However, we can say through circumstantial evidence that Syrian qanats were already in use during the Roman period (Adeel et al. 2008).

Unlike Lebanon and Israel characterized by regular precipitation, in Jordan, these qanats are found east of the Jordan River near Shunat Nimrun. Local inhabitants report that they are of Roman origin. An underground aqueduct, with numerous shafts, leads into Solomon's pool in Jerusalem. This tunnel collects its water from an infiltration gallery but may not be a true qanats (Cressey 1958). The previous works indicated that, at the first, Jingquen are located in Han Dynasty in China. In the deserts of Northwestern of the country (Turpan), the irrigation water used in the oases systems are mainly provided by the Jingquen resources. Thus, a local Museum of these Jingquens is created regard to their socio-historical importance. It forms a protected area for 1000 Jingquens with a total length of about $5000 \mathrm{~km}$ (Wulff 1968; Motiee et al. 2006).
The single most important component of Oman's irrigated oasis agriculture is the famous falaj system itself. The falaj irrigation system is an important source of water for agricultural land and domestic water. It permits the collecting of water resources that are, otherwise, hard to tap in the prevailing geologically and topographically difficult land. Its social organisation and effective basin-based distribution system enable a surprisingly uniform irrigation of fields (Wilkinson 1977; Abdel-Rahman and Abdel-Magid 1993; Al Ghafri et al. 2001; Al Marshudi 2001; Shahalam 2001). While debate about the origins of the aflaj irrigation system and the development of irrigated agriculture in the region is ongoing, archaeological and palaeo-climatic evidence indicates that the Oman Peninsula played a key role in it, as it did in the invention of Sarooj cement (Al Rawasa et al. 1998). Aflaj in Oman are classified into three types according to their water source: ghaily (50\%), daudi (25\%), and ainy aflaj $(25 \%)$ of the total aflaj in Oman. According to Al-Hatmi and Al-Amri (2000), the tunnel of Daudi aflaj has $0.5-1.0 \mathrm{~m}$ width, $0.5-2.0 \mathrm{~m}$ height, and up to $12 \mathrm{~km}$ in length [e.g., Falaj Daris in Nizwa and falaj al-Malki in Izki (Al-Balushi Hamad Salim 1995)]. In addition, this type of aflaj is most difficult to construct which require time, workforce, and lot of money; it costs about 80,000 US\$ to dig a small qanat system with length of $2 \mathrm{~km}$ and mother well depth of $16 \mathrm{~m}$.

(Bonine (1989)). In general, one expects the flow of water through the daudi falaj to be more consistent than for the ghaili type. The ghaili falaj is a spate irrigation type, while the aini falaj is a spring type.

In the Loralai District of Balochistan Province in Pakistan, indigenous water management practices are regarded as the only important way to re-establish integrated water resource management fundamental for the survival of people in this arid region. The earliest historical evidence of the presence of a karez in Balochistan dates back to 2700 years ago. By the time of independence of Pakistan in 1947 and before the 1950-1952 drought, 22,000 karezes were operational in Balochistan. 50 years later, 12,000 karezes were still functional, but, today, only less than 4000 karezes have survived the latest drought from 1996 to 2003, which was also the longest and most severe drought in the history of Pakistan. The provincial government of Balochistan, with the assistance of the Government of Pakistan, has recently completed the rehabilitation of 105 karezes in the province. The rehabilitation work was limited to the widening of mother wells, repairing the vertical shafts, desilting of channels, lining of on farm distribution channels, and finding alternate sources of water for the dried karezes. Three delay action dams were built in the province to recharge karezes, but they all ran dry before the monsoon season approached (Khan 2008). 
The early settlers of the Yemeni mountainsides were thus forced to use every possible patch of soil for cultivation. In addition, they faced a challenge when the slopes started to become denuded, and high rainfall events were accompanied by severe soil erosion. According to Vogel 1987, the farmers established millions of terraced fields in the Yemeni highlands employed today. As soon as it rains, the runoff is funnelled by the artificial berms into broader channels which direct the water from the bare hillsides onto the terraced fields. Using the Yemeni Arabic term, the system of irrigation is called sawaji (Vogel 1987). Archaeologically in Yemen, the terrace construction dates back to at least the third millennium BC (Wilkinson 1999). Large parts of this terraced terrain have been cultivated continuously since that time. Until 50 years ago, people in the mountainous areas of Yemen were highly dependent upon rain-fed agriculture on the picturesque terraces that give Yemen its distinctive landscape character. Traditionally, water harvesting was an appropriate and brilliant solution for sustainable and secure food production.

The development of galerias system transmitted to Spain, and onwards to Latin America (Martínez-Santos and Martínez-Alfaro 2012) where they are largely referred to as galerias, although other names such as puquio and matrit also exist (Al Ghafri et al. 2003). Spanish gallerias, like as those found in Madrid, have long-since been replaced by municipal water systems (Martínez-Santos and MartínezAlfaro 2012).

\section{Current status of the mkayel}

The aflaj Irrigation Systems of Oman are ancient water channels from 500 AD located in the regions of Dakhiliya, Sharqiya, and Batinah. However, they represent a type of irrigation system as old as 5000 years in the region (UNESCO 2015). In 2006, five aflaj Irrigation Systems of Oman were added to the UNESCO list of World Heritage Sites: Falaj Al-Khatmeen, Falaj Al-Malki, Falaj Daris, Falaj Al-Mayassar, and Falaj Al-Jeela. According to the Ministry of Water Resources (MWR), the number of aflaj in Oman is estimated to be 11,000 , among which 4000 are major ones that are constantly flowing. Maintenance is frequently carried out to maintain maximum water flow rate of the falaj, since it is the main source of water for domestic and agricultural purposes. These aflaj are irrigating 26,500 hectares. The flow of aflaj of the UAE is of about 630 1/s (Rizk and Al Sharhan 2003). In El Ain region, there is seven operational aflaj feeding the oases with a flow of 315 1/s (Rizk and Al Sharhan 2003).

In Tunisia, the number of the functional mkayel decreased from 800 to 100 in 1957 and at 0 presently (Hamed 2011). In southeastern Morocco, in Tafilalet, the number of khettaras decreased significantly from 300 in the early twentieth century to 150 in 2000 (Ben Brahim 2003). The abandoned khettaras until 2004 were 262 out of the 308 counted khettaras in 1967 (Ouhassain 2004). According to National Agency of Water Resources (N.A.W.R) in Algeria, the number of foggaras dug in the Touat and Gourara is 1400; only 903 foggaras functional between 1998 and 2001. In Syria, Romani Qanats, the number decreased from 293 to 29 in 2006 (Lighhtfoot 1996). In Jordan, the 32 aflaj inventoried, only 8 are functional (Lighhtfoot 1996). In Yemen, the total number of qanats is 94 except 40 which remains functional until 1960. In Iran, qanats the number diminished from 50,000 (Ghorbani 2007) to 32,000 in 1950 (Bonine 1989). The gradual disappearance of foggaras is due to use of modern technology (pumps and boreholes) in the oasis, agricultural expansion, growing demands of domestic, the evolution of social problems (migration and inheritance), and industrial water use (Industrial sector of CPG). A drop in the groundwater table due to the overexploitation is the main cause of the mkayel destruction in many countries, especially in Tunisia.

At the beginning of the 21st century, the United Nations Convention to Combat Desertification (UNCCD) had been interested in the role of traditional technology in combating desertification. For this matter, the Traditional Knowledge World Bank was established through support from UNESCO and the Toscana Government of Italy to provide the existing data. Desertification is closely linked to management of water resources, agricultural and climate change processes, and changes of biological diversity and vegetation cover. The impacts and magnitude of desertification change over time and vary from place to another. This variability is driven by the intense climate aridity combined with the pressures people put on the ecosystem.

Drought and desertification are the main, inter-linked climatic challenges in the MENA regions, and dwindling water resources will pressure the water resources and threaten the wellbeing of the human race. For these reasons, the solution is sought in modern technology, such as desalinization of seawater, but the traditional techniques of sustainable water use could be found on the ground. In an ideal future, the reuse of qanats for sustainable water management could contribute to such a lifestyle. The countries that have qanats should carefully consider whether government subsidies should be directed towards renovation of these systems. In Syria, the success renovation of qanats is technically possible; however, a thorough social and hydrological assessment is required in advance.

\section{Conclusions and recommendations}

In ancient times, the North Africa enjoyed more rainfall than today. This situation changed around $4000 \mathrm{BC}$ when the socalled mid-Holocene moist phase came to an end and the climate started to become much dryer (Hamed et al. 2010). 
Since for thousands of years, the people living in dry lands have discovered many technologies to catch and use water. This traditional system called mkayel have been playing diverse roles with regards to the exploitation of groundwater, agricultural, domestic, and maintained the unique oasis ecosystem in the Sahara. This old system can enhance social and cultural diversity, and may be considered as a global international heritage. The advantages of the traditional systems such as their energy efficiency (based on the use of gravity), regulation of microclimate thanks to the planting structure (Safriel and Adeel 2005) good water quality, waste recycling systems, and sand dune stabilization techniques (Adeel et al. 2008) and permanent availability of water during all seasons make them attractive for the small communities in rural areas. They are also environmentally friendly systems representing efficient ways to insure sustainable groundwater exploitation in the El Guettar oasis (Tunisia).

The population growth, the overexploitation of groundwater, and changing socio-economic accelerate the abandonment of the traditional systems in North African region. With these societal changes, the modern drip irrigation systems would be beneficial in terms of meeting the growing water demands and would also protect the mkayel systems.

In addition, regard to their historical and cultural value, their maintenance encourages the traditional eco-tourism in and furnishes alternative income at local and national scales like El Guetar (Tunisia). The utilization of modern technology (pumps and drilling) is the main cause of decline the traditional systems. Consequently, the mkayel are being abandoned as shallow aquifers fall and galleries go dry (Lighhtfoot 1996), but there is another problem: change in lifestyle and way of thinking; the younger generation hates the jobs of farming and pulls towards the cities. Finally, governments could have a significant contribution in the maintenance of the mkayels systems by establishing a comprehensive local database. These databases could be very useful for academic studies seeking to improve the mkayels efficiency as a main source of water used for both irrigation and domestic needs. Therefore, the local communities also should contribute with the government in the preservation of such important water systems.

Acknowledgements The authors wished to express their sincere appreciation to the staff members of Gafsa Water Resources Division/Agriculture Ministry, the Regional Heritage of Gafsa, and the members of $\mathrm{CPG}$, for their help during field work.

Open Access This article is distributed under the terms of the Creative Commons Attribution 4.0 International License (http://creativeco mmons.org/licenses/by/4.0/), which permits unrestricted use, distribution, and reproduction in any medium, provided you give appropriate credit to the original author(s) and the source, provide a link to the Creative Commons license, and indicate if changes were made.

\section{References}

Abdel-Rahman HA, Abdel-Magid IM (1993) Water conservation in Oman. Water Int 18:95-10219

Adeel Z, Schuster B, Bigas H (eds) (2008) What makes traditional technologies tick? A review of traditional approaches for water management in drylands. Hamilton (ON), United Nations University

Ahmadi R, Ouali J, Mercier E, Mansy JL (2006) The geomorphologic responses to hinge migration in the fault-related folds in the southern Tunisian Atlas. J Struct Geol 28:721-728

Al Ghafri A, Inoue T, Nagasawa T (2001) Irrigation scheduling of Aflaj of Oman: methods and modernization. Graduate School of Agriculture, Hokkaido University, Japan. http://www.inweh.unu.edu/ inweh/drylands/Publications/Alghafri.pdf. Accessed Mar 2, 2005

Al Ghafri A, Inoue T, Nagasawa T (2003) Daudi Aflaj: the Qanats of Oman. In: Proceedings of the Third Symposium on Xinjang Uyghor, China. Chiba University, Chiba, Japan

Al Marshudi AS (2001) Traditional irrigated agriculture in Omanoperation and management of the Aflaj system. Water Int 26(2):259-264

Al Rawasa A, Hago AW, Corcoran TC, Al Ghafri KM (1998) Properties of Omani artificial pozzolana (sarooj). Appl Clay Sci $13(4): 275-292$

Al Tikriti WY (2002) The south east Arabian origin of the falaj system. Proc Semin Arab Stud 32:117-138

Al-Balushi HS (1995) A study of the hydrological and social aspects of Falaj Al- Iraqi, Ibri, Oman, M. Sc Theses, Center for Arid Zone University of Wales, Bangor, UK

Al-Hatmi HK and Al-Amri SS (2000) Aflaj Maintenance in the Sultanate of Oman. In: The Proceeding of the First International Symposium on Qanat, Ministry of Energy, vol. IV, Yazd, Iran, 8-11 May, pp 154-161

Ben Brahim M (2003) Les khettaras du Tafilalet (Maroc) Passé, present et future. In: Internationals Frontinus symposium, Luxembourg, 2-5 Oct

Besser H, Mokadem N, Redhaounia B, Ayadi Y, Faten K, Harabi S, Hamed Y (2018) Groundwater mixing and geochemical assessment of low enthalpy resources in the geothermal field of Southestern Tunisia. Euro Mediter J Environ Integr. https://doi. org/10.1007/s41207-018-0055-z

Bonine ME (1989) Karezes, field systems, and morphology: retangularity on the Iranian Plateau. In: Beaumont P, Bonine ME, McLachlan K (eds) Karez, Kariz and Khattara: traditional water systems in the Middle East and North Africa. Whitstable Litho Ltd., Cambridgeshire, pp 35-57

Bonine BPM, Mc Lachlan K (1989) Qanat, Kariz and Khattara: traditional water systems in the Middle East and North Africa. The Middle East Centre, School of Oriental and African Studies, University of London in association with Middle East \& North African Studies Press, London

Bordereau P (1986) La capsa ancienne, op.cit, p30

Celle H (2000) Caractérisation des précipitations sur le pourtour de la Méditerranée occidentale. Thèse, Doctorat Es Sciences. Universite d'Avignon et des pays de Vaucluse, France, p 222

Celle-Jeanton H, Travi Y, Blavoux B (2001) Isotopic typology of the precipitation in the western Mediterranean region at three different time scales. Geophys Res Lett 28(7):1215-1218

Charbonnier J (2014) Groundwater Management in Southeast Arabia from the Bronze age to the Iron age: a critical reassessment. Water Hist. https://doi.org/10.1007/s12685-014-0110-x

Cleuziou S, Tosi M (1998) Hommes, climats et environnements de la Peninsule arabique a l'Holocene. Paleorient 23(2):121-135

Cleuziou S, Tosi M (2007) In the shadow of the ancestors: the prehistoric foundations of the early Arabian civilization in Oman. Ministry of Heritage and Culture, Muscat 
Cordoba JM (2013) New perspectives about Iron Age and the oasis culture in the Oman peninsula. Two conclusives seasons at al Madam (Sharjah, UAE). Isimu 16:139-151

CPG (Tunisian phosphate industry) (2010) Consommation hydriques des eaux souterraines dans le bassin de Gafsa sud, p 58

Cressey GB (1958) Qanats, Karez, and Foggaras. Geogr Rev 1:27-44

Custodio E, Kretsinger V, Llamas MR (2005) Intensive development of groundwater: concept, facts and suggestions. Water Policy 7:151-162

Desruelles S, Fouache E, Eddargach W, Cammas C, Wattez J, Beuzen-Waller T, Martin C, Tengberg M, Cable C, Thornton C, Murray A (2016) Evidence for early irrigation at Bat (Wadi Sharsah, northwestern Oman) before the advent of farming villages. Quatern Sci Rev 150:42-54

DGRE (Direction Générale des Ressources en Eau) (2011) Annuaire de l'exploitation des nappes de la Tunisie. DGRE, Tunis

Dlala M, Hfaiedh M (1993) Le séisme du 7 Novembre 1989 à Metlaoui (Tunisie Méridionale): une tectonique active en compression. C R Acad Sci Paris 317(II):1297-1307

English PW (1998) Karezes and life worlds in Iranian plateau villages. Yale Environ Sci Bull 103:187-205

Gayar AE, Hamed Y (2018) Climate change and water resources management in Arab countries. AG-Euro-Mediterranean and surrounding regions. Advances in science, technology \& innovation. Springer International Publishing, Berlin. https://doi. org/10.1007/978-3-319-70548-4-31

Ghorbani B (2007) Aglance at historical Qanats in Iran with an emphasis on Vazvan Qanat in Isfahan. International history seminar on irrigation and Drainage. Teheran, Iran, May 2-5

Hadji R, Yacine A, Hamed Y (2018) Using GIS and RS for slope movement susceptibility mapping: Comparing AHP, LI and LR methods for the Oued Mellah Basin, NE Algeria. In: Recent advances in environmental science from the Euro- Mediterranean and surrounding regions. https://doi.org/10.1007/978-3319-70548-4-536

Hamad A, Baali F, Hadji R, Zerrouki H, Besser H, Mokadem N, Legrioui R, Hamed Y (2018) Hydrogeochemical characterization of water mineralization in Tebessa-Kasserine karst system (TunisoAlgerian Transboundry basin). Euro-Mediter J Environ Integr 3(1):7. https://doi.org/10.1007/s41207-017-0045-6

Hamed Y, Dassi L, Tarki M, Ahmadi R, Mehdi K, Ben Dhia H (2010) Groundwater origins and mixing pattern in the multilayer aquifer system of the Gafsa-South mining district: a chemical and isotopic approach Environ. Earth Sci. https://doi.org/10.1007/s1266 5-010-0806-X

Hamed Y, Redhaounia B, Ben Sâad A, Hadji R, Zahri F (2017) Groundwater inrush caused by the fault reactivation and the climate impact in the mining Gafsa Basin (Southwestern Tunisia). J Tethys 5(2):154-164

Harou JJ, Lund JR (2008) Ending groundwater overdraft in hydrologiceconomic systems. Hydrogeol J 16(6):1039-1055

Hassanzadeh R, Abbasnejad A, Hamzeh MA (2011) J Environ Stud $36: 101$

IGES (2008) Climate change policies in the Asia-Pacific: re-UNITING climate change and sustainable development. Kanagawa, Japan

Khan FF (2008) Zarh-Karez: A traditional water management system striving against drought, increasing population, and technological change, book what makes traditional technologies tick? A review of traditional approaches for water management in drylands, $\mathrm{p} 65$

Konikow LF (2002) Groundwater depletion and over-exploitation: a global problem. Denver Annual Meeting, Geological Society of America, Oct 27-30

Lighhtfoot DK (1996) Moroccan Khettara: traditional irrigation and progressive desiccation. Geoforum 27(2):261-273
Magee P (2004) The impact of southeast Arabian intra-regional trade on settlement location and organization during the iron age II period. Arab Archaeol. Epigr 15:24-42

Mamou A (1989) Caractéristiques et évaluation et gestion des ressources en eau du Sud tunisien. Thèse Doctorat. Univ. de Paris Sud. France

Mamou A, Kassah A (2002) Eau et développement dans le sud tunisien. Cahier du CERES, Série Géographique no. 23. Tunis $268 \mathrm{p}$

Martínez-Santos P, Martínez-Alfaro PE (2012) A brief historical account of Madrid's qanats. Ground Water 50(2012):645-653

Mokadem N, Hamed Y, Ben Sâad A, Gargouri I (2013) Atmospheric pollution in North Africa (ecosystems-atmosphere interactions): a case study in the mining basin of El Guettar-M'Dilla (southwestern Tunisia). Arab J Geosci 7:2071-2079. https://doi.org/10.1007/ s12517-013-0852-2

Mokadem N, Younes H, Hfaid M, Ben Dhia H (2015) Hydrogeochemical and isotope evidence of groundwater evolution in El Guettar Oasis area. Carbonates Evaporites, Southwest Tunisia. https://doi. org/10.1007/s13146-015-0235-8

Mokadem N, Demdoum A, Hamed Y, Bouri S, Hadji R, Boyce A, Laouar R, Saad A (2016) Hydrogeochemical and stable isotope data of groundwater of a multi-aquifer system: northern Gafsa basin (Central Tunisia). J Afr Earth Sci 114:174-191

Morris BL, Lawrence ARL, Chilton PJC, Adams B, Calow RC, Klinck BA (2003) groundwater and its susceptibility to degradation: A global assessment of the problem and options for management. Early warning and assessment report series, RS. 03-3. United Nations Environment Programme, Nairobi, Kenya

Morrison GMP, Revitt DM, Ellis JB (1990) Metal speciation in separate stormwater systems. Water Sci Technol 22(10-11):53

Motiee H, Mcbean E, Semsar A, Gharabaghi B, Ghomashchi V (2006) Assessment of the contributions of traditional qanats in sustainable water resources management. Int J Water Resour Dev 22(4):575-588

Orchard J, Orchard J (2007) The third millennium BC oasis settlement of Oman and the first evidence of their irrigation by Aflaj from Bahla. In: Archaeology of the Arabian Peninsula through the Ages. Proceedings of the International Symposium (7th-9th May 2006). Ministry of Heritage and Culture, Sultanate of Oman, Muscat, pp 143-173

Oshima K (2001) Utilization of Khattara and organization of water users at Tizgaghin in Morocco. J Daito Asian Stud 2:27-42

Oshima K (2004) The future prospects of khattara and roles of organization of water users. J Daito Asian Stud 5:59-72

Ouhassain M (2004) Système d'irrigation traditionnelle par khettaras dans le sud-est Marocain- Fonctionnement et Rôle dans la sauvegarde de la vie dans les oasis. Revue HTE, ${ }^{\circ} 129$, juin, pp 8-10

Rizk ZS, Al Sharhan SA (2003) Water resources in the United Arab Emirates. Water Res Perspect Eval Manag Policy 50:245-264

Safriel U, Adeel Z (2005) Dryland systems, Chapter 22

Shahalam AM (2001) Review of Omani aflaj systems: an element of national water resources, technology and economic developments. Sci Technol 6:1-14

Tlili M (2009) Gafsa et les villages oasiens avoisinants : de la vie communautaires (du début de XIII e.s à 1881). Livre ISBN : 978-9973-05-166-0

Trousset P (1986) De la montagne au désert; "limes" et maitrise de l'eau. Revue de l'occident musulman de la méditerranée, 41-42

United Nations (1992) Interregional workshop on groundwater overexploitation in developing countries. Gran Canaria, Canary Islands, Spain, United Nations, Department of Technical Cooperation for Development. Prepared by J. Dijon and E. Custodio. New YorkBarcelona. U.N. INT/90/R43, New York

Vogel H (1987) Terrace farming in Yemen". J Soil Water Conserv 42(1):18-21 
Vrbo J, Lippanen A (2007) Groundwater resources sustainability indicators. UNESCO, Paris

Wilkinson JC (1977) A Study of the Aflaj of Oman. Water and tribal settlement in South-east Arabia. Oxford University Press, Oxford
Wilkinson T (1999) Settlement, soil erosion and terraced agriculture in highland Yemen: a preliminary statement. Proc Semin Arab Stud 29:183-191

Wulff HE (1968) The qanats of Iran. Sci Am 218(4):94 